\title{
赤痢の家庭内伝播に関する疫学的研究
}

\section{Studies on the mechanism of familial transmission of bacillary dysentery}

\author{
札幌医科大学衛生学教室 (主任 金光正次教授) \\ 等々力 達 也 \\ Tatsuya Todoriki
}

Department of Hygiene, Sapporo Medical College

(Director: Prof. M. Kanamitsu)

\begin{abstract}
緒 言
赤㢉が流行する機序には同時感染と連銷感染があり， 前者では爆発流行, 後者では家庭内散発の型で現われる ことが多く, この両者の機序は古くから疫学研究者の興

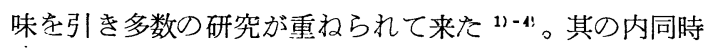
感染による流行では発生患者が多く, その㾔学的条件も 比較的単純であるために，其の機序は現象的並びに理論 的に詳細に研究されている(5)6)。

とれに対して家庭内感染では発生患者の数が比較的少 いとと, 病原菌の侵入径路, 一次患者の感染力, 家族の 感受性, 患者の発生と処理の時期などが続発患者の発生 に著しく影響することから, その機序は同時感染の場合 に比へて著しく複雑である。従来ての方面の研究は主と して理論的見地から研究されたものが多いが, 上述の点 を考えると, その前侁先ず家庭内伝播関与する諸因子 の質的条件を充分に検討する必要があると思う。以上の 事から本報ではこれに関与する因子として家庭内感染源 と続発患者の性及び年踰を採り, それが赤痢の家庭内伝 播にいかなる意義を有するかを検討した。とれと共に過 去に抢ける赤痢の流行と集団免疫との関係を, 赤痢つ家 庭内伝播の観点から研究した。
\end{abstract}

\section{研究方法}

1. 資料. 昭和 26 年より 33 年に至る 8 年間に, 札幌市 立厚生病院（伝染病院）に入院した赤痢患者のカルテふ ら赤痢菌が証明されたもの, 及び専門医師の診断により 臨床的に赤痢と確定されたものを選び, 合計 561 世帯 896 名の患者を得た。またこれとは別に炤和 29 年より 31 年の間に北海道内に発生した集団発生による赤痢患者を
上述と同じ基準で調査し, 合計 94 世帯 229 名の患者を得 た。これらの世帯について患者の性, 年柃及び世帯の人 員, 家庭内に抢ける一次患者及で続発患者の発病日, 一 次患者の感染径路, 分離された赤礿菌の型及び初期症状 を調查した。

2. 研究方法. 各家庭で最初に発病した患者を Index Case (I.C.) としn，とれを性及び年秢別に分けた。 次に各群に抢ける I.C. の発病日を基準にとり, 続発患 者をその発病日に従って配列し, その日別発生を全患者 に対する比率で表わした。しの日別発生比率曲線の形か ら患者を一次と二次（三次以上をも含む）患者に区分し 両者の性及び年踰が患者の発生に関し相互にいかなる関 係を示すかを検討した。但し集めた資料には患者が単発 に終つた例が著しく多く，とれを加えて日別発生の比率 を求めると零日, すなわち I.C. の発生日に著しく集積 し, 二次患者の発生曲線が明膫でなくなる為に, 本報で は単発例と I.C. を除いた患者について 日別比率曲線を 画いた。また各群について以下の式により家族集積率と 家庭内二次䍜患率を求め, 上述の日別発生曲線方ら得た 成績と対照した8)。乙の場合はもち論単発患者とI.C.を 加えて算出した。

$$
\begin{aligned}
& \text { 家族集積率 }=\frac{\text { 家族集積発生患者数 }}{\text { 総患者数 }} \times 100 \\
& \text { 家庭内二次罹患率 }=\frac{\text { 家庭内二次患者 }}{\text { 家庭内曝露人口 }} \times 100
\end{aligned}
$$

\section{成 績}

1. 同時感染と連顉感染による患者の日别発生の比較 第 1 図は水道污染による赤痢集団発生の際69世帯から 発生した 158名の患者と, 食物を介して菌が移入された 


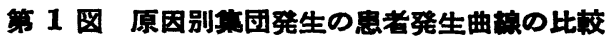

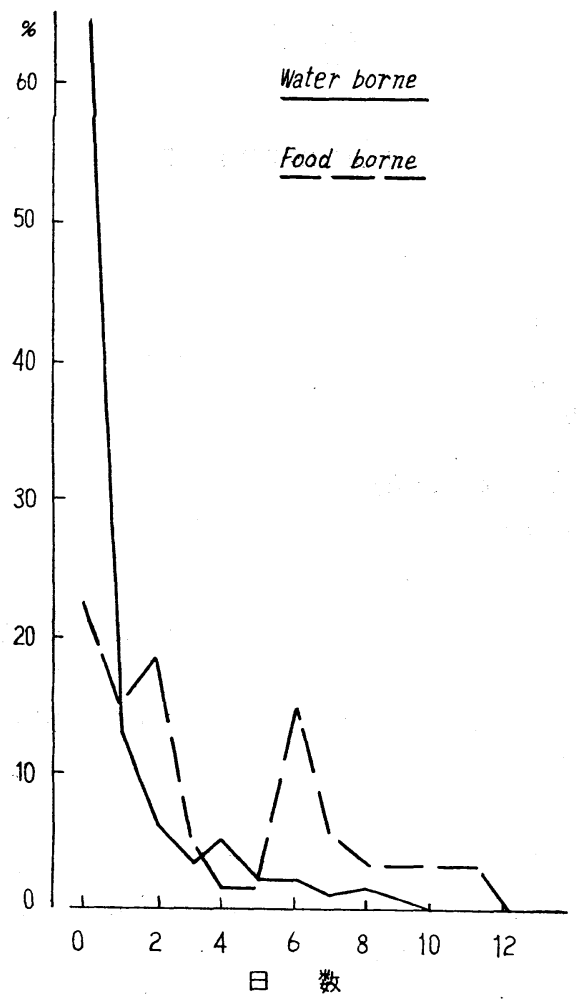

25世帯の患者71名について, その日別発生を比較したも のである。同時感染による患者の発生は零日に著しく多 く，全患者の63\%を占めるが，それより第 3 日目に至る まで急激に減少し，4 日目にわずか増加するが，その 後次第に減少しながら10日目に至り完全に 終熄してい る。とれに対し食物による流行ては零日の発生患者は全 数の $22.5 \%$ に過ぎず，第 3 日目までの患者を加えても 61.5\%程度で前者に比べて明らかに少い。患者の発生は 第 4 日より 5 日目まで著しく減少するが，第 6 日目に至 って再び増加し以後次第に減少しながら第12日目に完全 に終㹸している。との第 4 日五ら 5 日に見られる明瞭な 谷により，一次患者と二次患者を区分する事が出来る。 また零日の発生患者の割合が水系流行に比べて著しく小 さく, かっその後の低下も不規則なのは, 食物の場合は 家庭の全員が同時にそれを摂取するとは限らず，またそ の摄取量も不同なためと思われる。乙れに対し水系流行 でははじめの 3 日間に全患者の $85 \%$ 證病しているが， これはほとんどの家族が同時に菌の感染を受け，感受性 者は浑とんどすべてしの期間内に発病しているととを意 味している。従って感染を免れた者が少いために残存す る感受性者も少く, これが日別発生に扛いて明瞭な谷を
第 2 図 赤堋㭧者心年齡分布

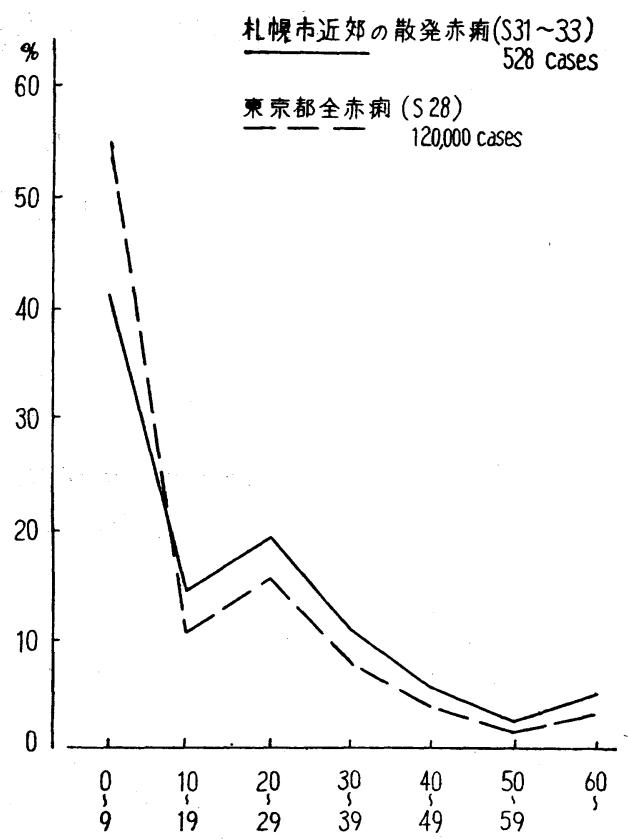

示さない原因と考えられる。

\section{2. 家庭内初発患者の年糙と二次患者の発生との関係}

第 2 目は昭和29-31年に招ける札幌市の赤痢届出患者 528 名の年踰分布を示したものであって, 全患者の中 0 一 9 才の幼児が $42 \%$ 占め著しく多い。10-19才では 14 \%に減少するが, 20-29才では再びやや増加し，以後年齢 と共に漸次減少している。との傾向は四に示した昭和 28 年の東京都の成績とよく一致し, 我が国の赤莉䍜患の年

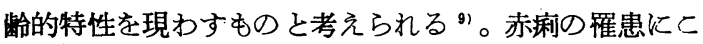
のような著明な年柃差がある事より，家庭内感染に执い ても初発患者の年秢がその後の二次患者の発生に影響す るのではないかと考え，との点を検討した。前述の定義 によれば I.C. はその家庭に最も早く出現した患者であ るが，二次患者に対する感染源としての意義を考慮する そ, I.C. に伴って発病した他の一次患者の影響を無視す る事は出来ない。よって本章では資料の中から患者の日 別発生曲線の 性状により一次患者と認定された 者が, I.C. と同じ年齢階級に属している家庭を集め, その家庭 に打ける二次患者の発生状況を比較した。

第 3 図は単発患者を除き同じ家庭に 2 名以上の患者が 発生した例についての成績て, 二次患者は全年踰に亘っ ている。図に示すょうに I.C. 及び一次患者が 0-9 才 の群ては $1-3$ 日目に不規則な浅い谷を形成した後 $4-$ 5 日目に第 2 峰を現わし, 以後時日と共に次第に低下し 
第 3 図 I.C. 及び一次㭧者の年柃别 発生曲缐の比茭

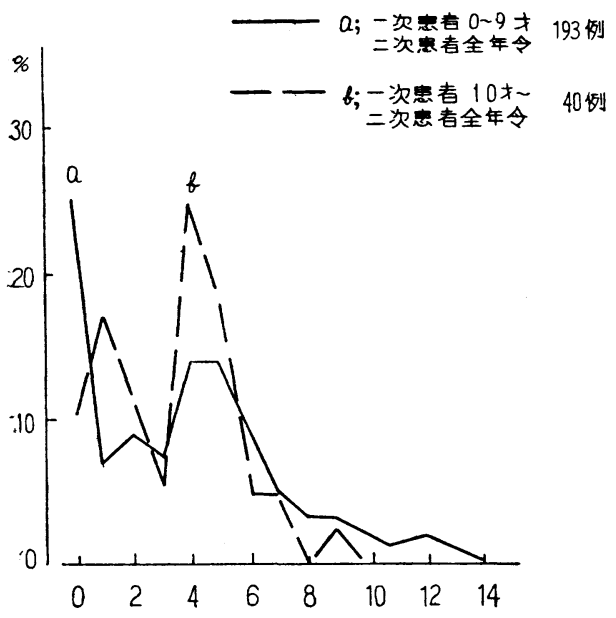

こ13日目に至って患者の発生が消退している。とれに対 し初発患者が10才以上の年長者の群では第 2 日に深い们 と, 第 $4-5$ 日に著明な第 2 峰を形成し, 以後急速に低 下して患者の発生は第9 日に消失し, 流行の終熄次前群 より 4 日も早い。しの成績から概観して両群共に第 2 日 悹での発病者を一次患者, 第 3 日以後を二次患者 (三次 以降を含む）と認定してよいと思う。

図で注目されるのは各群患者の日別発生状況が明か心 異る事である。すなわち 2 日目末での一次患者について 見ると，それが幼児の場合にはその大多数が I.C. の患 児と同日に集積発生しているが, 年長群ではか心る傾向

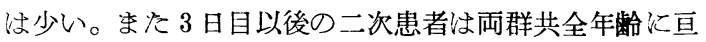
っているにかかわらず，その 4-5 日目に抢ける集積は 後者の方が著しく強い。第 1 表恃 I.C. の年齢とその家 族化扔ける二次罹患率及び家族集積率の関係を示した成 績で, I.C. が $0-9$ 才の家庭では10才以上の場合に比べ 乙二次罹患率仙約 6 倍, 家族集積率に括いても約 3 倍高 い。との成績は一見第 3 図と矛盾するようであるが，前 述のごとく図の発生曲線は二次患者の発生経過を明示す る為に, 単発例と I.C. を除いて画いている。後に述べ るょうに I.C. が幼児の際に比べて年長者の場合には単

第 1 表 I. C. の年齢别の家庭内二次䍜患 率および家族集栍率

\begin{tabular}{c|c|c}
\hline I. C. & $\begin{array}{c}\text { 家庭内三 } \\
\text { 次羅患率 }\end{array}$ & 家族集積率 \\
\hline $0 \sim 9$ 歳 & $7.3 \%$ & $58.8 \%$ \\
10 歳 & 1.3 & 17.9 \\
\hline
\end{tabular}

発例が著しく多く, 従って它の群の家族集積率は図の曲 線 b 功推測するよりはるかに低いものになる。Cの 事住家庭内二次罹患率を算出する際, 単発例の特に多い 年長者の群では曝露人口の増加として現われる為に，そ の值に影響する事は当然である。とれに対し I.C. が幼 児の群では二次患者の集積の他に, I.C. と同日の発病者 の多い事が集積率を著しく高める因子となっている。

\section{3. 二次患者の年鈆とその日别発生の関係}

前章の成績は初発患者の年齢がその後の患者の発生と いかなる関係があるが検討したもので，その際二次患 者としては全年齢に亘る者を用いた為に，二次感染にお 汀る年齢的意義を観察する事は出来なかった。しかし前 揭第 2 図及び前章の成績から赤痢の罹患と年齢との間に 密接な関係がある事を知り，同様の事は当然二次患者に ついても検討すべき問題となった。第 4 図は同じ家庭か ら発生した患者がすべて 0-9才の群と，10才以上の群 をとってその日別発生曲線を描き，乙れを前揭第 3 図の 相対応する一次患者の年齢群の曲線と比較した成績であ る.すなわち家庭に発生した患者のすべてが 9 才以下の 幼児の場合， $\mathrm{A}$ 図の曲線 $\mathrm{a}$ に示すように零日すなわち I.C. と同日に発病卞る者が著しく多いが，翌日に至って 急激に減少し, 以後不規則に変動しながら次第に減少 し，その間認きべき谷や峰を示さない。曲線 b は 2 日 目末では前群と等しく 9 才以下の患者であるが，3 日目 以後峘全年齢つ患者拿む場合の日別発生であって, 両 曲線にはさまれた斜線の部分は10才以上の二次患者を意 味している。との成績から同じ幼児の患者に 接触して も, それに上る年長の二次患者俚 3-4 日の潜伏期を経 て一時に集積発生する傾向があるが，幼児の二次患者は かかる集積を示さず，その発生は連続的であると言え る。

次に発生患者がすべて10才以上の年長者の場合は，B 図の曲線 a に示すょうに二次患者は 3 日の 間隔で 規則 的に集積発生しながら次第に減少し, その経過は先に述 びた幼児の場合に比べてきわめて対照的である。てれと 峛図の曲線 b を重ねた図の 斜線の 部分は幼児の二次患 者を意味するが, その大多数が $3-4$ 日目に集積する事 が見られる。すなわち同じく幼児の二次患者であ感染源 が幼児の際は集積発生しないが，感染源が年長者のとき は集積する傾向が強い。これは感染源と同時に発病した 幼児患者がこの群から除かれている為であるが，その第 2 峰が $\mathrm{A}$ 図のそれに比べて著しく高いのは, 一次感染を 免れた幼児に招いても赤㢉に対する感受性が依然として 高い事を意味するものと思う。 


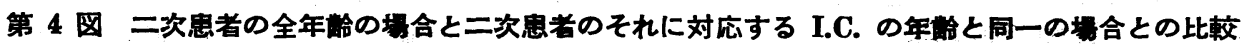

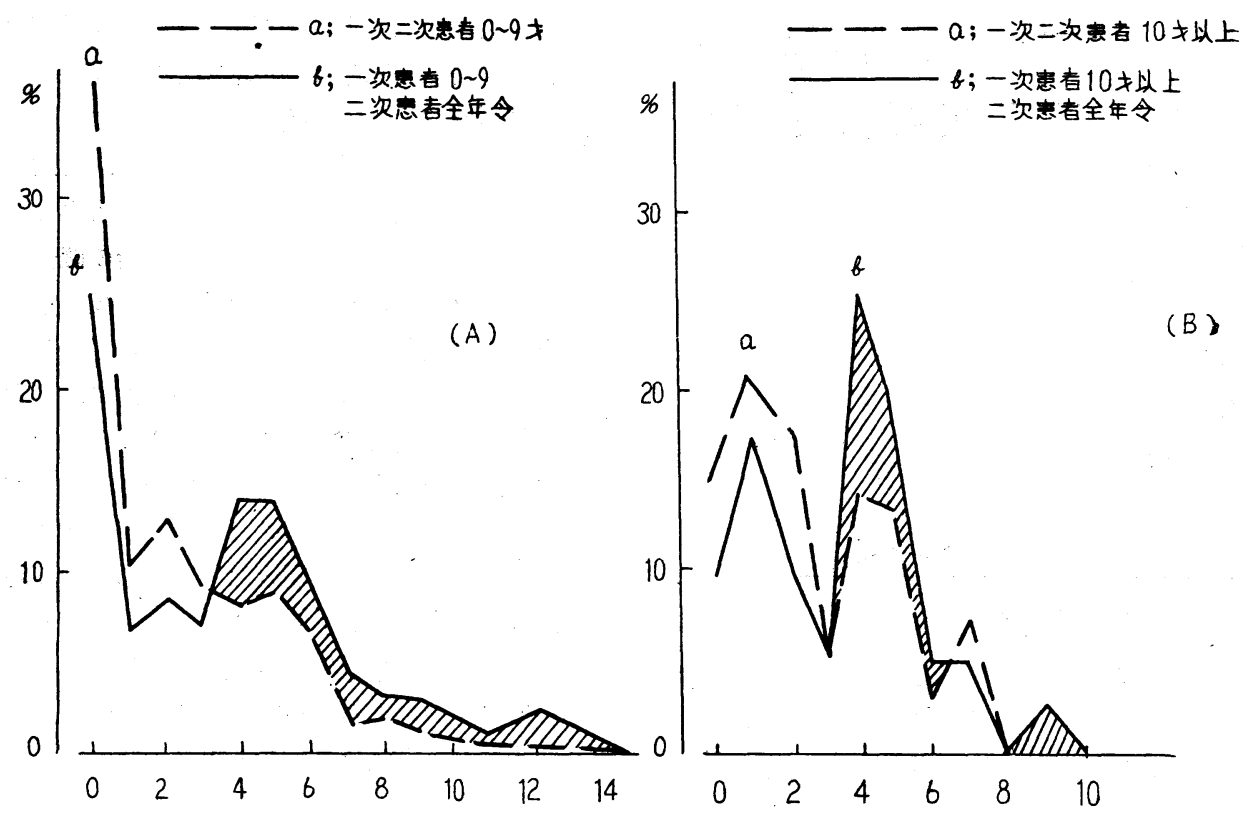

第 5 図 I.C. 及び一次患者並びに二次患者の年齢别発生曲線の比較
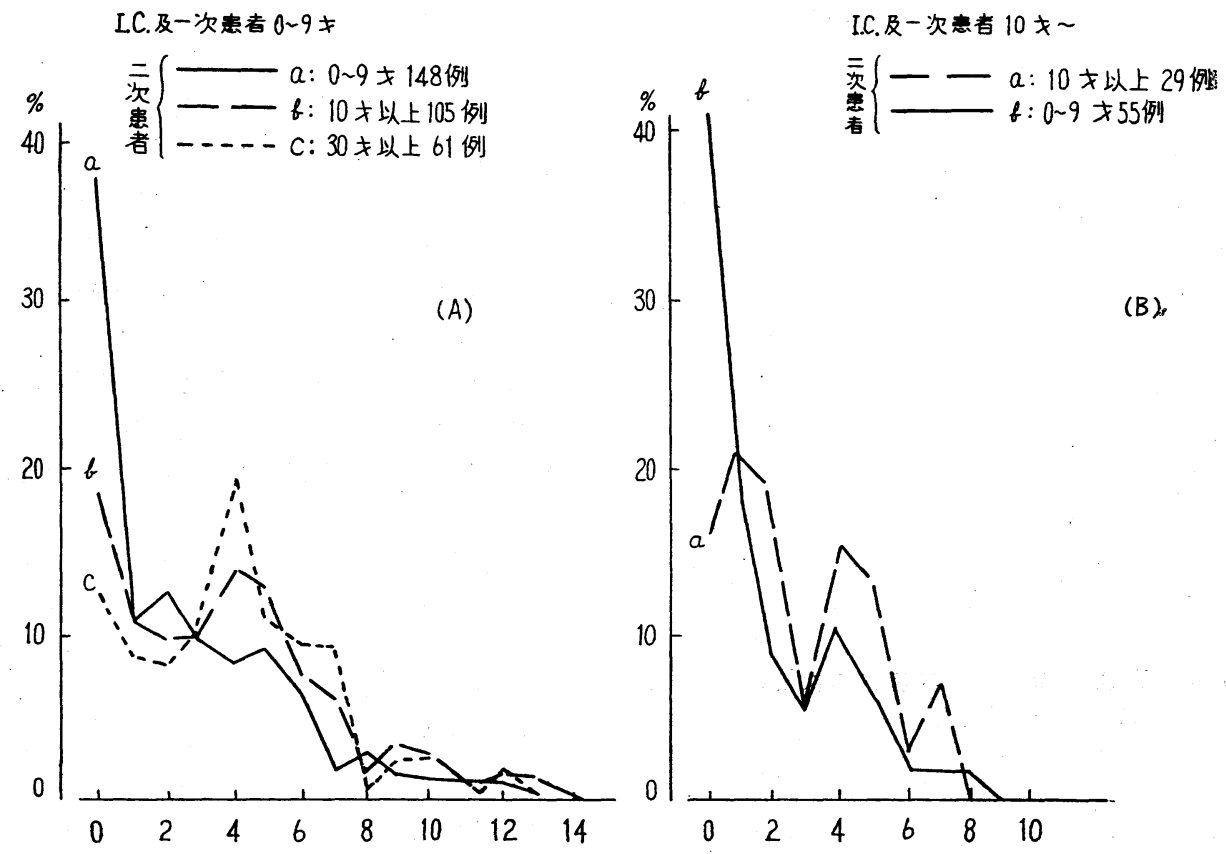
第 5 図性同じ年辂つ感染源に接触発病した二次患者 その年齢によって区分し，その日別発生を比較した成績 である。感染源すなわち一次患者が 9 才以下の幼児の場 合は，A図のどとく二次患者の年路が増加するに伴って 3 -4 日目に集積する傾向が強くなり，特に30才以上の 群に著明である。Cれと同じ傾向は B 四のごとく一次患 者が10才以上の年長者の場合にも見られ，乙れは二次患 者の年齢的特性として注目される。

\section{4. 一次及び二次患者の性についての検討}

周知のごとく食物による赤痢の集団発生では，それを 取汲う者が感染源となっているととが少くない。家庭で その仕事に従事する者の多くが六性である事を考える と, 初発患者の性は先に考察した年踰々共に赤㢉の家庭 内伝播を支配する重要な因子となるであろうととは想像 䨅くない。更に家庭に患者が発生した時, その看護に 当るものも多くは女性であるここから，赤痢ではそれに よる感染の機会も多いと考えられる。従って性の問題注 感染源のみならず二次患者にも関係すると推定して以下 わ検討を抢てなった。

\section{第 2 表 初発患者および二次患者の年齢別 性别の比較}

\begin{tabular}{|c|c|c|c|c|c|}
\hline \multicolumn{2}{|c|}{ I.C. 及び一次患者 } & 二次患者数 & I. C. & \multicolumn{2}{|c|}{ 二次患者数 } \\
\hline \multirow{2}{*}{ 0 9 歳 } & $\hat{o}$ & 53 & \multirow{2}{*}{$0 \sim 9$ 歳 } & $\hat{\delta}$ & ㅇ \\
\hline & 우 & 40 & & 31 & 62 \\
\hline \multirow{2}{*}{10 歳 } & $\hat{\delta}$ & 5 & \multirow{2}{*}{ 10歳～ } & \multirow{2}{*}{10} & \multirow{2}{*}{12} \\
\hline & $q$ & 17 & & & \\
\hline
\end{tabular}

すなわち前章と同様に I.C. 一次及び二次患者を年齢 で2 分した後更に性別し, 各群患者の日別発生状況を比 㜞した。その結果一次患者が幼児の場合化掞いて, 二次 患者を示す峰が男子群に比べ女子群がやや高いと云了成 績を得たが，その他には特別の傾向柱認め得なかった。 しかし初発患者の性質と二次患者の発生数との間に次の ごとき注目すべき関係を見出した。すなわち第 2 表に示 すように, I.C. 及び一次患者が 9 才以下の幼児の家庭に 発生した総計 93 名の二次患者を見ると, 前者が男児の場 合は 53名, 女児の場合は 40 名で両群の間に大差がない。 しかしこの初発患者を綜合し，二次患者を性別すると， それが男性の群では 31 名に過ぎないが, 女性では 62 名と なり前者より 2 倍も多い。次に I.C. 及び一次患者が10 才以上の家庭に発生した22名の二次患者について同様に 観察すると, 前者が男性の場合はわずか 5 名であるに対 し，女性の場合17名となり 3 倍以上も多い。しかし初発
患者を綜合し二次患者を性別すると, 後者の発生数は男 性群10名，女性群12名でほとんど等しい。

以上つ成績から初発患者が幼児の際は, それが男児 なると女児なるとを問わず，それによる二次患者の発生 数には著しい差はないが, それが年長者の際沈女性の方 が男性よりも明らかに多くの二次患者を発生させる。李 た初発患者に接触した家族からの二次患者は, 前者が幼 児の際は女性に多く発生するが，年長者の場合にはこの ような性別の差異はないと云える。との成績仗家庭に捛 ける赤痢の伝播機序を示す事実として興味がある。すな わち家庭内感染源としての女性の疫学的意義は幼児の年 齢で次認められず，10才以上になって著明に現われるの は，Сの年齢の女性が家庭で食物を取扱うことが多い為 と考えられる。また初発患者が幼児の場合に限り二次患 者に女性が多いの梳，赤㢉に対する性的素因と云うょり はむしろ患児との接触が多い為なるととを意味してい る。

第 3 表はとの資料について I.C. の性別と年踰別に家 庭内二次罹患率と家族集積率を求めて比較した成績で,

\section{第 3 表 初発患者の年龄別性别による家庭内} 二次䍜患率および家族集楀率の比較

\begin{tabular}{cc|c|c}
\hline I. C. & & $\begin{array}{c}\text { 家庭内三 } \\
\text { 炊羅患率 }\end{array}$ & 家族集積率 \\
\hline \multirow{2}{*}{$0 \sim 9$ 歳 } & $\hat{\delta}$ & 8.4 & 58.2 \\
& ㅇ & 5.5 & 51.8 \\
\hline \multirow{2}{*}{10 歳 } & $\hat{\delta}$ & 0.6 & 14.5 \\
& ᄋ & 2.3 & 37.1 \\
\hline
\end{tabular}

I.C. が 9 才以下の群について家庭内二次罹患率と家族集 積率を性別に見ると，両性の間に著しい差は見られない が，10才以上の場合岋男性に比べ女性つ方が家庭内二次 罹患率に捛いて約 4 倍, 家族集積率に捛いて約 2.5 倍高 く，前表の成績とよく一致する。

\section{I.C. の性及び年齢と患者の家庭内続発との関係}

前章までの成績は I.C. 及び一次患者の性，年齢が二 次患者の発生にいかなる影響を及ぼすが， 2 名以上の 患者が続発した家庭について検討したものである。しか し周知のでとく赤痢では患者が単発に終る家庭が少くな い。ふって本章では I.C.の性及び年齢が患者の続発に いか影響するかを検討した。

第 6 四は初発患者を性と年龄で区分し，各群に扔ける 単発例と複発例との割合を示したものである。すなわち I.C.の年齢を 9 才以下と10-39才, 40 才以上の 3 群に分 け，とれを性別にょり観察すると，初発患者が 9 才以下 
第 6 図 I.C, の年龄と家庭内杬発との関係

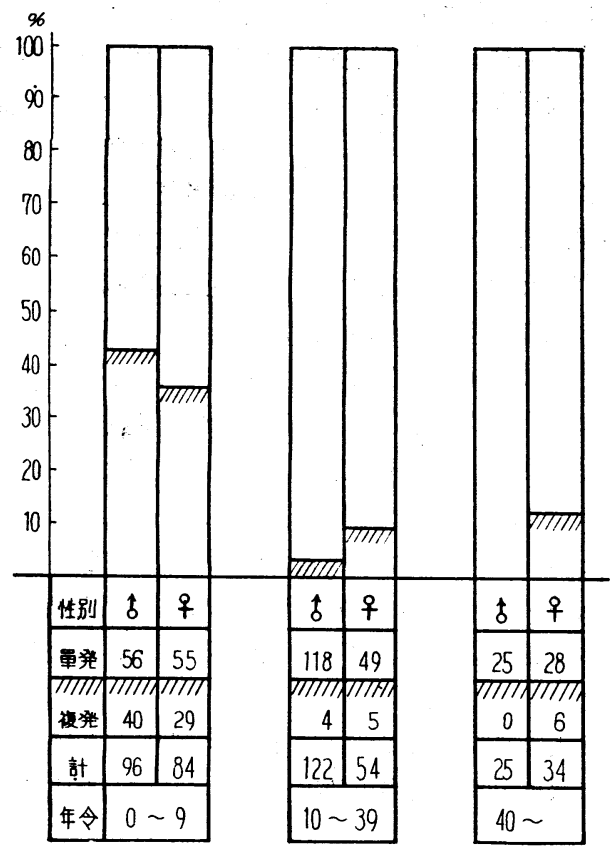

の男子であった96世帯の内, 単発は56世帯, 複発は40世 帯で両者の割合は $58 \%$ と $42 \%$ ある。また同年龄の女子

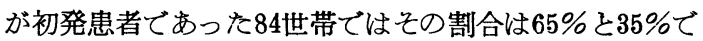
敦れも複発例が高率であるこれに対し初発患者の年齢 が増すと複発例の割合が著しく減少し，10一39才群では

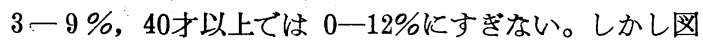
のことく年長群に抢ける複発例が初発患者が女性であっ た場合に著しく高率なととが注目される。

このことから, 若年の患者が最初に発生した家庭では 年長者が初発患者であった家庭に比へて複発する傾向が 著しく強いが，その際初発患者の性による差は少い。し かし初発患者が年長の場合には, それが女性の蹬男性に 比べて患者が褯発する㑯向が明らかに高いと云える。

以上の成績から I.C. が年長者の時は, 幼児の場合よ りも患者が単発に 終る 家庭が圧倒的に多い事を知った が，しかし年長者は赤痢に罹患しても自覚症状の軽い者 が多く，幼見に比べて発見され難い事が知られている101 従って患者の単発率を問題にする際には, 特に年長患者 の検出が単発と複発とにかかわらず, 同じ精度でおこな われているかどうかを検討する必要がある。その為本報 の資料方ら10才以上の単発患者亡, 同じ年龄で幼児の初 発に伴って発病した者を選び, その中受診前の初期症状 の記載された63名と33名についてその症状を比較した。

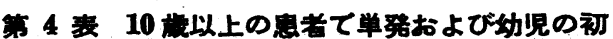
発に伴って発病した者の初期症状の比較

\begin{tabular}{|c|c|c|c|c|c|}
\hline \multirow{2}{*}{$\begin{array}{l}\text { 最\&症状 } \\
\text { の激しか } \\
\text { つた日の } \\
\text { 下痢回数 }\end{array}$} & \multirow{2}{*}{$\begin{array}{l}\text { 発 } \\
\text { 生 } \\
\text { 様 } \\
\text { 式 }\end{array}$} & \multicolumn{3}{|c|}{ 下琍以外の症状 } & \multirow{2}{*}{$\begin{array}{l}\text { 合 } \\
\text { 計 }\end{array}$} \\
\hline & & な し & $\begin{array}{l}\text { 腹痛, 悪心 } \\
\text { 䇠の中 } \\
1 \sim 2 \text { 種 } \\
\end{array}$ & 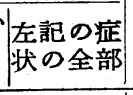 & \\
\hline \multirow{2}{*}{9 回以下 } & 単発 & $1(1.6)^{\%}$ & 20 & 1 & 22 \\
\hline & 複発 & $11(33.3)$ & 8 & 1 & 20 \\
\hline \multirow{2}{*}{ 10 19 回 } & 単発 & 0 & 18 & 4 & 22 \\
\hline & 厔発 & 0 & 3 & 0 & 3 \\
\hline \multirow{2}{*}{ 20回以上 } & 単発 $\mid$ & 0 & 10 & $9(14.3)$ & 19 \\
\hline & 複発 & 5 & 5 & 0 & 10 \\
\hline \multirow{2}{*}{ 合＼cjkstart計 } & 単発 & $1(1.6)$ & 48 & 14 & 63 \\
\hline & 複発 & $16(48.5)$ & 16 & 1 & 33 \\
\hline
\end{tabular}

第 4 表はその成績で, 1 日の下痢回数が 9 行以下で他に 何らの症状を認めなかった軽症者住, 単発群 1 名 (1.6 \%) に対し複発群11名 (33.3\%) に達している。次にて れと反対に 1 日の下㢉が 20 行以上で, 同時に腹痛, 悪 心, 発熱を認めた定型的患者は, 単発群の 9 名 $(14.3 \%)$, に対し複発群には 1名む見られない。との成績は年長患 者の発見の精度が単発と複発の場合とでは異る事を推定 させるに充分である。すなわち表の下欗に示したょうに 年長の単発患者のほとんぞ総ては下永の他にも何らかの 症状を有する者であるが，とれは換言すれば軽症患者で 単発した者は㴗とんど発見されていない事を意味してい る。これに対し複発患者では下峲以外に症状のある者と 無い者が抢よそ相半ばし，との場合は症状の軽重により 患者の発見が左右されない事を示している。すなわち症 状の軽い単発患者の大多数は家庭て陰蔽されるが, 幼児 が罹患するとてれが機縁となつて他の患者も症状の軽重 にかかわりなく発見される事を意味している。

\section{6. 家族人数と家庭内繶発との関係}

前章までは家庭から発生した患者を初発患者と続発患 者とに分け，とれらの患者の年齢と性による家庭内続発 を観察したのであるが，患者の発生の基盤になる感受性 者の数についての考慮をしなかった。よって本章では二 次患者の発生が家族人員の数によりいかに影響されるか を観察した。

第 7 図はその成績で，I.C.の年齢を 0一9才と10才以 上の 2 群に分け, 患者の発生世帯の内複発世帯が占める 割合と家族人員数との関係を示したものである。此の図 に打いて各家族人数群の世帯数は $14-54$ である。

I.C. が 0-9才の場合， 3 人以下の家族では複発例が 
第 7 図 I.C. の年剚别による 家族数と 家庭内繶発の関係

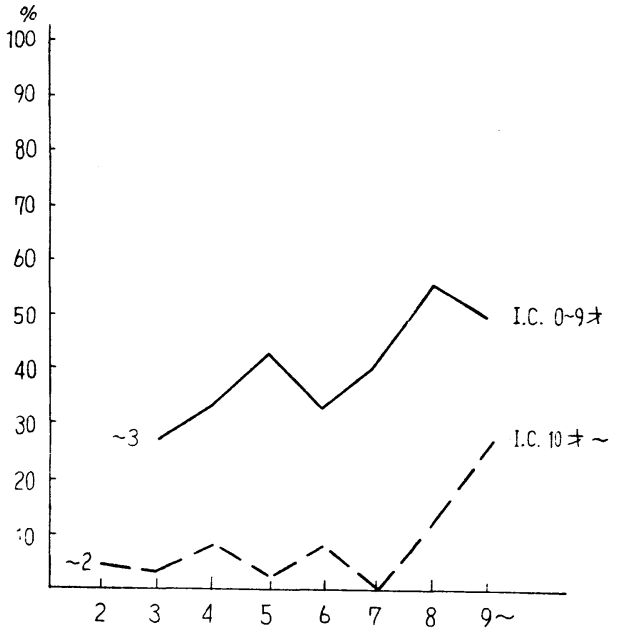

$27 \% て ゙$ ，以後家族人数が増すに従って複発例が増加し， 9 人以上では $50 \%$ で約 2 倍近く上昇する。I.C. が10才以 上では 2-6人家族注で $5 \%$ 内外で著しい変化はない が， 8 人家族から急激に上昇し， 9 人以上の群では $26 \%$ に達するが, 図に見るょうに複発の割合は前群沁比べて 著しく低い。一般に家族人員が增すにつれてその中の感 受性者も増し, 従って患者が複発する割合も増大寸ると 予想されるが，Сの成績から初発患者の年秢によつては 必ずしもその想定が当はまらない事を知った。

次に I.C. を年龄と共にその性にょって区分し, 複発 患者の出現する割合を見ると第 8 図のごとくである（各 家族人数群の世帯数浪 14-18)。す流わち I.C. が 9 才以 下の年少者の場合汇はその性別による複発率には著しい 差異を認めないが, I.C. が10才以上の場合つ複発は前者 が男子の際怯きわめて少く，深とんぞが女子の場合に限 られている事が注目される。また I.C. が女子の際注家 族人数の増加伴って漸次複発率も上昇する傾向が認め られる。

\section{7. 赤阙菌型と家庭内流行との関係}

周知つょうに赤痢菌には種々の型があり, その細菌学 的性質と共に，それによる流行の性状が研究されてい

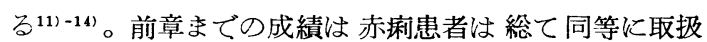
い, 感染菌の型については考慮しなかった。本章では菌 型が家庭内感染と二次患者の発生にいかなる影響を及注 すかを観察した。菌型として本報の患者資料の中で最も 多い Fl. 2a，3a，2b をとり，単発例を除きそれぞれ 111 例, 29例, 49例を得た。とれは同じ家庭内の患者の細菌
第 8 図 I.C. の年粭别, 性别による 家族人数 と家庭内続発との関係

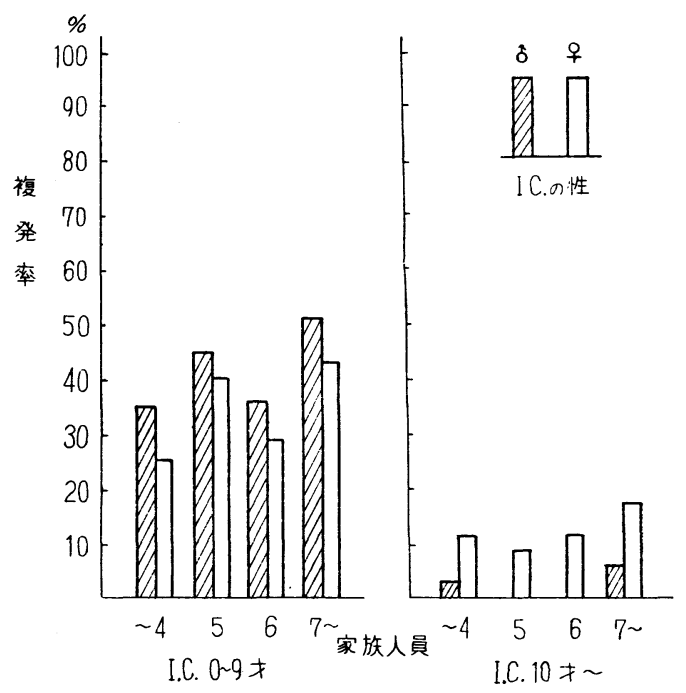

第 9 図 菌型による発生曲線の比較

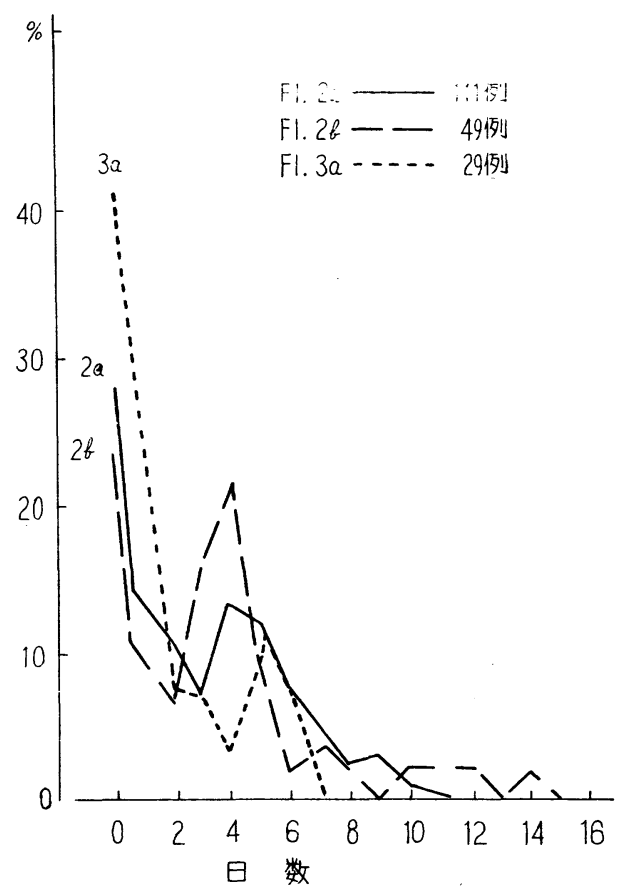

検査成績から，同型菌の感染による発病と判定された者 である。各群患者の性と年齢を綜合してその日別発生曲 線を画くと第 9 四のどとくなる。

すなわち零日に招ける一次患者の割合は Fl. 3 a 群は 著しく高く, $2 \mathrm{a}, 2 \mathrm{~b}$ 両群はとれに比べ明らかに低い。 


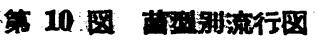

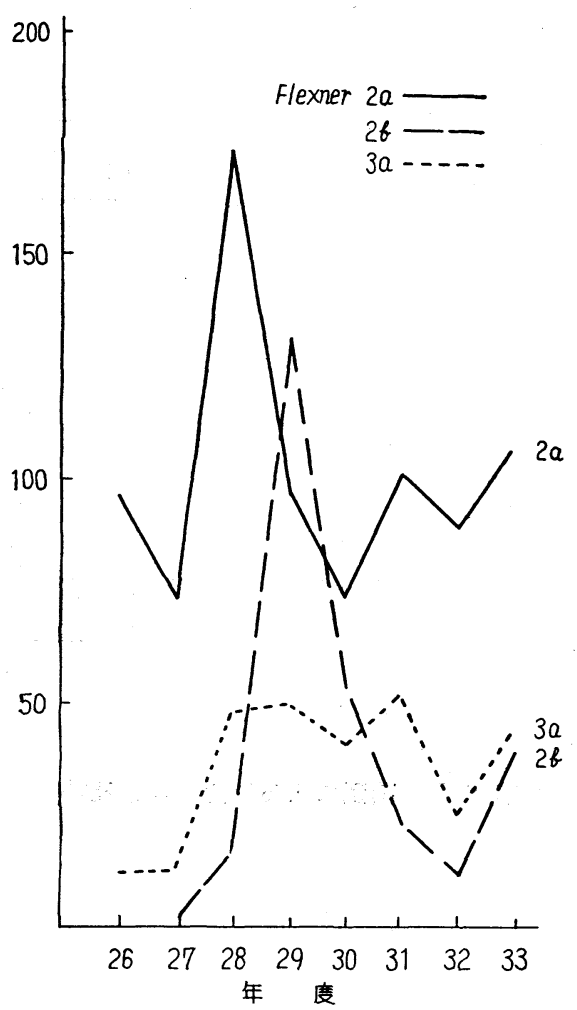

また二次患者との境界を示す谷の位置は $2 \mathrm{~b}$ 群仗 2 日 目, $2 \mathrm{a}$ 群は 3 日目, $3 \mathrm{a}$ 群仙 4 日目にあってそれぞれ
1 日ずつ遅れている。次炕第2盽の゙位置は 2a，2 b 群は 共に 4 日目で等しいが, $3 \mathrm{a}$ 群は 5 白目にあり, その峰 の高さは $2 \mathrm{~b}$ 群が最も高く, 次て $2 \mathrm{a}$ 群, $3 \mathrm{a}$ 群刀順に 低くなっている。生た $2 \mathrm{a}$ 群の二次患者は第 4 日以降漸 次減少し, 10日目に至って患者の発生がやむが, $3 \mathrm{a}$ 群 に掞いては第 2 峰以後急激に減少して 6 日目に至って終 熄している。2 b 群では更に第三, 第四次患者を思わせ る不規則な波動を画きながら第14日までに亘って発生し ている。すなわち患者の日別発生曲線の形状と流行が終 熄するまでの経過は菌型により明らかに異る。

疫学の見地からすれば, 赤㢉の感染伝播は病原菌の性 状と宿主集団の感受性との相互作用と見るべきものであ る。ょって後者の因子として過去に抢ける赤痢の感染に よる集団免疫を想定した。第 10 図怡昭和 26 年から 33 年の 間に札幌市厚生病院に収容された赤痢患者の菌型の稚移 である15)。すなわち Fl. $2 \mathrm{a}$ 菌は26年に扢いて既にかな りの程度に浸淫しているが, 28 年に著しく増加し, 以後 一時減少したが 31 年以降再び増加の傾向を示している。 Fl. 3a 菌の浸淫はこれに比べて著しく低く, 28年以降 からやや增加したが $2 \mathrm{a}$ 菌に比べればその患者は $1 / 2$ 以 下に過ぎないFl. $2 \mathrm{~b}$ 菌は昭和 28 年から検出され, 翌 29年札幌市に本菌による流行があった為一時増加した $か^{161}$, その後速汃減少し之の 袷出は $3 \mathrm{a}$ 菌よりも低 い。との成績示ら札幌市に扮ける赤㢉の 浸淫度はF!．2 a 菌が著しく高く,Fl. $3 \mathrm{a}$ 及び $2 \mathrm{~b}$ 菌はこれに比べて. 遙かに低く, 従ってその浸淫度に応じ集団免疫が生じる

第 11 図赤蔽型别思者の年龄分布
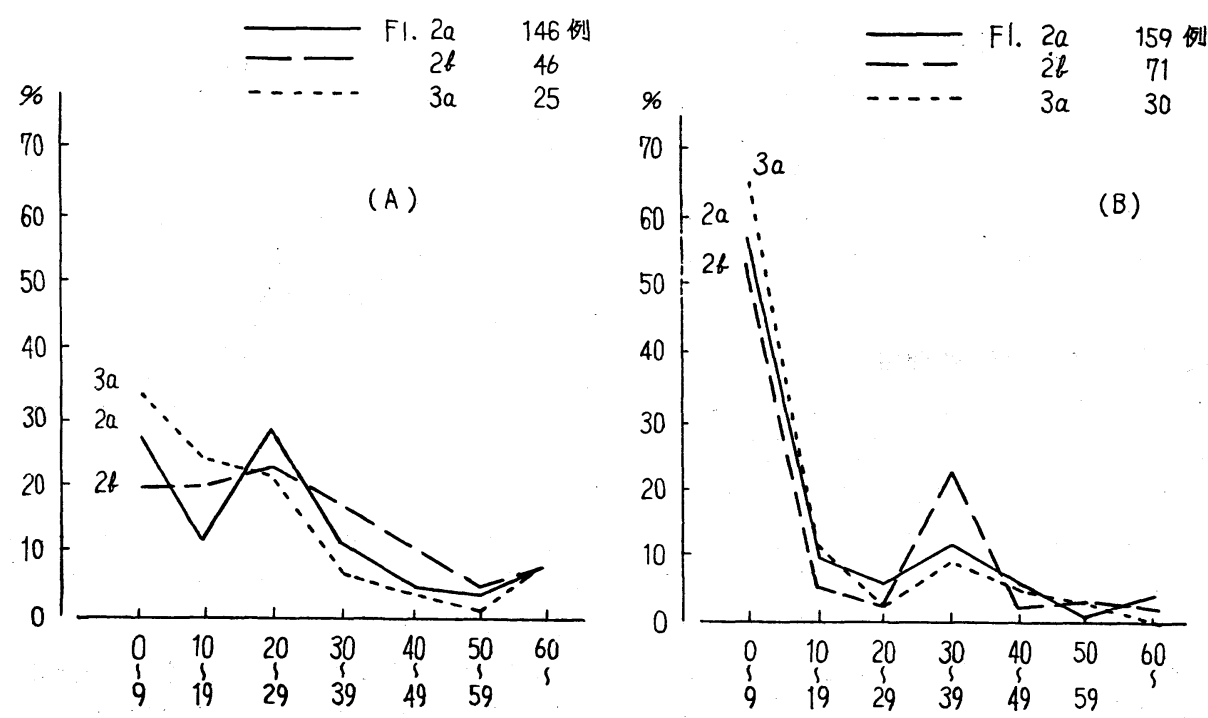
と仮定すると，市民の免疫は $2 \mathrm{a}$ 菌に対して最も高く， $3 \mathrm{a}, 2 \mathrm{~b}$ 菌に対する免疫はとれょり著しく低いと推定 される。

しの考えを前提として再び第 9 四を見ると， $2 \mathrm{a}$ と 2 b 菌による患者発生曲線に执いて， 0-1 日目の発生割 合は両者共抢上そ等しいが，二次患者を示寸第 2 峰は 2 b 群の方が明らかに高く, またその後の患者の発生も 2 a 群に比べて著しく延長して抢り, 感染に曝露された家 族の $2 \mathrm{~b}$ 菌に対する集団免疫が $2 \mathrm{a}$ 菌に対するそれょり も低いと云う上述の想定とよく一致する。しかし同様に 集団免疫が著しく低いと考えられる $3 \mathrm{a}$ 菌患者では, 二 次患者の峰が更に低く, その発現も扔くれしかも患者の 発生の終熄も早く, 上述の想定と相反している。との点 を更に検討する為に次の観察を行った。

第11図は 各菌型患者の 年龄分布を 比較したものであ る。先ず $\mathrm{A}$ 図の単発例について見ると, Fl. 2 a 患者は 0一 9才と 20--29才に集積する二峰型を示すが， 2 b 群 では29才に至る間は流とんど等しく，以後年榆の増加と 共に減少している。 $3 \mathrm{a}$ 患者は 9 才以下の幼児に最も多 く, 以後年齢 と共に急激に減少し, 30 才以上では本菌患 者は他型に比べて明らかに少い。成人患者の単発例の大 多数は外食などによる家庭外感染に因るものであるか ら, その発生も各型赤冽菌の浸淫度と抬よそ比例すると 考えられ，との成績は先に第10図で推定した所とよく一 致している。次に複発患者の年龄分布を見ると，B 図の ことくいずれの菌型であ幼児が著しく多い。しかし成年 層の発生比率は Fl. $2 \mathrm{~b}$ が最む高く, $2 \mathrm{a}$ とれに次ぎ, $3 \mathbf{a}$ は最む低い。とれらの複発患者は家庭内で同型菌患 者から感染を受けた者であるから, 接触感染の条件が各 菌型共均等と仮定すれば，との成績は 各菌型の 感染力 （或は伝播力）と宿主の感受性との相互作用の結果を示 寸むのである。眓の成人層に見る Fl. $2 \mathrm{~b}$ 患者の著明な 峰は原因菌の性状の他に, 既に述べた本菌に対する集団 免疫の低い事が関聠している事を推定させるが，同程度 に集団免疫が低いと認められる $3 \mathrm{a}$ 菌に括いて，Cの年 齢患者の比率が $2 \mathrm{a}$ 患者よりも低い事は, 本菌の感染力 が著しく低い為ではないかと思われる。

第 5 表は以上の 3 菌型患者群について家庭内複発率と 二次罹患率を比較した成績である。先ず複発率を患者単 位で見ると, Fl. $2 \mathrm{~b}$ が最も高く, $2 \mathrm{a}$ Cれに次ぎ， 3 a では最も低い。またとれを世帯を単位として観察する と, Fl. $2 \mathrm{a}$ と $2 \mathrm{~b}$ では大差ないが, $3 \mathrm{a}$ 群の 複発率は これょり明らかに低い。次に表で Fl. $2 \mathrm{a}$ と $2 \mathrm{~b}$ の複発 率は世帯単位で 観察した 時には潘とんぞ等しいのに対
第 5 表 菌型别の很発率および家庭内二次䍜患率

\begin{tabular}{|c|c|c|c|c|}
\hline \multirow{2}{*}{ 菌 } & \multirow{2}{*}{ 型 } & 複 & 率 & \multirow{2}{*}{$\begin{array}{c}\text { 家庭内 } \\
\text { 二次罹患率 }\end{array}$} \\
\hline & & 患者単位 & 世帯単位 & \\
\hline Fl. & $2 a$ & $\begin{array}{cc}\% & \text { 例数 } \\
52 & 305\end{array}$ & $\begin{array}{cc}96 & \text { 例数 } \\
32 & 215\end{array}$ & 37.7 \\
\hline & $2 \mathrm{~b}$ & 117 & 34 & 46.6 \\
\hline & $3 \mathrm{a}$ & 39 & 78 & 30.4 \\
\hline
\end{tabular}

し，患者単位で比較すると後者の方が約10\%高い。とれ は $2 \mathrm{~b}$ 菌が家庭内に侵入した時は $2 \mathrm{a}$ 菌の場合より続発 する患者の数が多い事を示し, 前者に対する家族の集団 免疫の低さを推定させる。乙れに対し同様に集団免疫が 低いと推定される Fl. 3a 菌による患者の 複発率が, 観察単位の如何にかかわらず他のいずれの菌型患者より 低く, 更に二次罹患率も最低である事から， $3 \mathrm{a}$ 菌の感 染力（家庭内伝播力）は他型菌上り低いと考元たい。

\section{考 察}

戦後我が国では各種の伝染病が 激減したにかかわら ず，赤㢉のみは未だに流行が絶えず，年々10万に近い患 者が発生している17)。赤㢉の流行が跡を断たない理由と してて上下水道や食品衛生管理の不備もあげられるが, 最 近注目されるのは家庭内感染患者が増加している事であ る。すなわち赤祚つ家族集積率は諸種伝染病の中第 1 位 を占め, しかもその率は年年上昇する傾向があり ${ }^{18)}$, 最 近の統計によれば患者の $12 \sim 15 \%$ は家庭内感染によるも

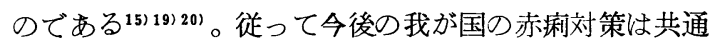
の飲食物の污染防止と共に, 家庭内感染の防止に注がれ ねばならない211。赤㢉の家庭内感染と伝播の機序につい ては古くから研究されているが，てれに関与する各要因 の質的な問題を深く検討した研究は意外に少い。私は最

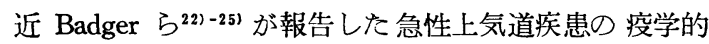
研究に示唆を受けて, 感染源とその家族の性及び年齢が 赤痢の家庭内伝播に及湆す意義を検討した。しの研究に 際しては感染源と続発患者を区別する必要があり，てれ に㹥通常患者の日別発生曲線による方法が用いられてい

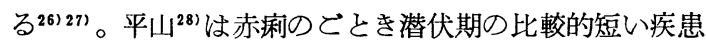
では，ての方法により両者を区別する事は困難であると 述べているが，本報に示したように患者を性及び年齢に より適当に群別すれば，多くの場合しの方法で両者を判 別し得る事を知った。この際問題になるのは日別発生曲 線少ら続発患者と判定した者の中に, 家庭内に潜在する 保菌者あるいは家庭外六らの感染者の混在を否定し得な い事である。しかしその可能性は認められるが，それが 
特定の家庭に偏って現われる理由はないのて，本報では かかる誤りはすへての家庭に均等に分布すると考えて， それをすべて家庭内続発患者と見做した。以下本報の成 績て注目された点について考察を加えたい。

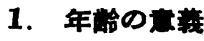

幼児の赤浰に対する感受性が成人に比べて著しく高い 事示ら, 家庭に感染源が存在すれば初めに罹患し易いの は幼児であり，その数も成人ょり多い事は当然である。 私の成績に执いても感染源の性状の如何にかかわらず, それと同日及び 1 日以内に発生する患者の大多数は 9 才 以下の幼児である。また二次患者が年長者の場合はほと んぞの例に括いて日別発生曲線は平均 3 日の間隔で二次 あるいは三次患者を意味する波動を画いているに対し， 幼児の場合にはこれがはなはだ不明膫である。これは幼 児の赤礿は潜伏期が短いので ${ }^{29}$, 一次と二次患者の発病 日の間隔が短縮する為と思われる。また年長者の続発䍜 患が上述のような波動を示すのは，赤㢉に対する感受性 が低い年長者ては, 家庭内の感染源の密度がある程度ま で高まって初めて有効接触が起る為ではないかと思う。

以上は続発患者の年龄についてであるが，感染源にお いても年齢的因子が重要な事を知った。すなわち一次患 者が幼児の家庭では，それが年長者の場合より患者の続 登が明加に多い。その理由として考えられるのはその看 護なぞで接触感染する機会の多い事て，その際特に年長 女子の罹患が多いのはとれを亭付けるものである。ま た初発患者が幼児の家庭ては流行の期間が延長する事を 認めたが，乙れ性幼の赤莉には症状の重い者が多く， 従って経過も長引く為便家族の感染機会も延長する結果 と思う。しかし本報で指摘したょうに成人の患者は多数 陰蔽されており，幼児の患者が発生して初めてそれが明 るみに出される事が多いと云う事実も，乙の問題に関係 しているのを見逃してはならない”。その意味で幼児患 者は家庭に潜む年長赤㢉患者を検出する探針とも云えよ 万。

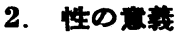

赤莉の家庭内感染と䍜患者の性との関係については石 田 $^{303}{ }^{31}$ ，平山 ${ }^{81}$ ，松田 ${ }^{211}$ の報告があり，いずれも成年 女子に多く，とれを看護の影響に帰している。本報ては とれと共に感染源としての意義をも検討し，成年女子は 赤浰の家庭内伝播に重要な 意義を 有する 事を 明玑に た。すなわち年長女子が感染源となった家庭ては, 同年 男子の場合に比へ続発患者は 3 倍多く, た反対に接触 者となった場合の罹患は男子ょり 2 倍も多い。更に成年 男子が感染源でる家庭で, 患者は単発に終る例が圧
倒的に多いのに対し，成年女子の場合は家族人数の多少 にかかわらず, 二次患者の発生を見る事が少くない。成 年女子は家庭に沶いて食事に携わると共に，炒児の哺育 看護に当る事功，との成績はある程度予想されたとは 云元，本報の分析でかくも明確な意義が証明されたのは 注目すべを事と思う。

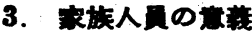

Badger ら ${ }^{251}$ は急性上気道疾患の 䍜患率が 家族人員数 に比例すると述へているが, 泉 ${ }^{32}$ は同様の現象を赤痢で も認めた。乙れは家族構成が大をくなるに伴い感受性者 数も增す為を考えられるが, Arbona ら ${ }^{331}$ が指摘するよ うに居住密度の上昇による接触機会の増加むその一因で あろう。私の成績む抢よそとれと一致するが，家族人員 の增加に伴う赤莉患者の複発率の增加俚, 感染源の年柃 により異る事を認めた。すなわち感染源が幼児の場合に は両者は招上そ平行するのに対し，年長者の際は家族人 員が 7 名に至るまでは複発率に流とんぞ差がなく，8名 以上になって初めて複発率も大をく上界している。その 理由は余り明かてないが，ての成績から年長患者の感染 力は幼児の患者に比べて低いとも云える。Imelik ら"19 家族人員が同じでも，有児家庭に抢ける赤峲患者の複発 率が無児家庭より著しく高い事を報告し, Hodges ら ${ }^{35)}$ も急性消化器疾患において同様の観察をしている。本報 では観察方法が異るので直接比較する事は出来ないが, 幼児患者及び年長患者のみよりなる 2 群の日別発生曲線 の形が質的汇異る事を指摘した。

\section{4. 赤珮に対する算団免废}

赤峲に対する免疫については, 年路別抗体保有状況や 再感染と菌型の関係 ${ }^{14)}$, 大流行後に招いて同型赤莉患者 の発生が著しく少い事 ${ }^{36)}$, 赤痢流行地区の年次的移動現 象年なを゙からこれを肯定する説むあるが，一般には未だ 認められていない(37) 28)。

私は二次患者の発生状況はその集団の免度を示す指標 であると云う Badger ら ${ }^{24}$ の考えに基き, 赤峲患者をそ の菌型によって群別し, その日別発生を過去に扔ける流 行菌型と対比して観察した。その結果浸淫度の高い Fl. $2 \mathrm{a}$ 菌による患者の二次発生は, その程度の低い Fl. 2 b に比べて明かに低く, 過去の流行による集団免度を想 定した場合とょく一致した。また成人に見られる単発 患者の多くは家庭外感染によるものであるが，この点に 抬いても両型菌の浸㳗度に合致した。所が Fl. 3 a 菌の 浸淫度は $2 \mathrm{~b}$ 菌より更に低いにかかわらず，本菌型患者 で注二次䍜患が著しく低く, 集団免疫を想定した場合と 相反する成績となった。併し各型患者の家庭内複発状況 
と成年層の単発患者の状況から, 私㹥これを家族の感受 性よりはむしろ菌自身の性状に起因するものと考えた。 とれが本菌の感染云播といかなる関係があるかは不明で あるが, 疫学的に興味ある事実と思う。

\section{結 論}

1. 赤礿の家庭内伝播の機序を知る為に, これに関与 する質的因子として感染源と続発患者の性及び年龄を選 び，家庭内伝播に打けるその意義を検討した。

2. 年泠的因子は感染源及びそれによる二次患者の発 生汇密接に関係し, 感染源が幼児の家庭では患者の続発 傾向が高い。末た二次患者が年長の場合はその日別発生 曲線が特異な波動を画くに対し, 幼児の場合はとれが明 瞭でない。

3. 性的因子として年長女子が感染源の家庭では患者 の続発が多く, また幼児が初発した場合にも男子に比べ て年長女子に続発患者が多い。

4. 年長患者の発見の精度はその家庭の幼児の罹患の 有無により著しく影響される。

5. 各菌型による患者の家庭内続発と過去の流行菌型 との関係から, Fl. $2 \mathrm{a}$ の伝播には家族の 集団免疫が影 響し, また Fl. $3 \mathrm{a}$ 菌は他型赤痢菌より伝播力が弱いと 考えられる。

\section{交 献}

1) N. T. J. Bailey: The Mathematical Theory of Epidemics. Charles Griffin \& Co. 1957.

2）堀内：日本公采衛生学会総会， 8, 64, 昭 28 .

3）堀内：日本公衆衛生雑誌，2，349，昭 30.

4）堀内：日本公衆衛生雑誌，2，351，昭 30 .

5) P. E. Sartwell : Amer. J. Hyg. 51, 310, 1950.

6）堀内：日本公衆衛生雑誌，3，18，昭 31 .

7) 齊藤絜編：公衆衛生学, 上巻, 95 頁, 金原出版 会社, 昭 31.
8）平山：衛生統計， $3(2), 12$, 昭 25 .

9）立花他：赤浰及び疫麻, 中外医学社, 昭 29 .

10) 小張 : 最新医学, 12, 1617, 昭 32 .

11) J. Watt : Amer. J. Hyg., 50 263, 1949.

12）阿部他：日本医事新報, 1532 号, 3458, 昭 28 .

13) A. V. Hardy: Public Health Report, 55, 2101, 1940.

14）大城：日本公衆衛生雑誌， 2, 373, 昭 30.

15）富沢他：日本伝染病学会雑誌，31，66, 昭 32 .

16）富沢他：日本伝染病学会雑誌，31，52, 昭 32 .

17）厚生省：昭和 28 年赤痢実㦔調查成績，昭 30.

18）平山: 公采衛生, 9, 45 , 昭 26.

19）館林：公采衛生，9，7，昭 26.

20）石田：衛生統計，5(4)，9，昭 27.

21）松田：公衆衛生，16，2，昭 29.

22) G. F. Badger : Amer. J. Hyg. 58, 41, 1953.

23) G. F. Badger : Ibid. 58, 174, 1953.

24) G. F. Badger: Ibid. 58, 179, 1953.

25) G. F. Badger : Ibid. 58, 31, 1953.

26) W. H. Frost: Amer. J. Public Health, 28, 7, 1938.

27）平山：公衆衛生学雑誌， 5, 69, 昭 23.

28) 平山：疫学, 績交堂, 昭 33.

29）関他：日本伝染病学会雑誌， 31，65, 昭 33.

30）石田：衛生統計, $5(4), 7$, 昭 27.

31）石田：衛生統計， 5(3)，1I，昭 27 .

32）泉：東京女子医科大学雑誌， 28，873，昭 33. ·

33) G. Arbona : Amer. J. Public Health, 39, 195, 1949.

34) Imelik: Zeitschrift für Hygiene u. Inf. Krh. 127, 93, 1947.

35) R. G. Hodges : Amer. J. Hyg. 64, 349, 1956.

36) 黒木：日本伝染病学会雑誌， 16，429, 1942.

37) Jordan: Burrows Textbook of Bacteriology. Vol. II. (秋葉, 四方訳編), 146 頁, 創元社, 昭 28.

38) R. J. Dubos: Bacterial and Mycotic Infections of Man. pp. 397, Lippincott Co. 1948.

（受付 : 1960 年 1 月 3 日） 